\section{Check for updates}

Cite this: Mater. Adv., 2022, 3,2393

Received 17th December 2021, Accepted 14th January 2022

DOI: $10.1039 / \mathrm{d} 1 \mathrm{ma01195b}$

rsc.li/materials-advances

\title{
Transition metal ion-coordinated porous organic polymer to enhance the peroxidase mimic activity for detection of ascorbic acid and dopamine $\uparrow$
}

\author{
Muppidathi Marieeswaran and Perumal Panneerselvam (iD *
}

Porous organic polymers (POPs) have been fabricated with intriguing physicochemical properties, which can be used in a wide range of emerging applications. However, they show less activity in nanozymes. Attempts have been made to boost nanozyme activity with incorporation of nanoparticles into POPs. The importance of $\mathrm{M}^{2+}$ incorporation has been highlighted, which prevents leaching and agglomeration. In this study, we prepared transition metal ion-coordinated porous organic polymers $\left(\mathrm{Cu}^{2+} \mathrm{aPOP}\right.$, $\mathrm{Ni}^{2+}$ (POP and $\mathrm{Co}^{2+}(\mathrm{aPOP})$ by a mechanochemical method. As-prepared $\mathrm{Cu}^{2+} \mathrm{aPOP}, \mathrm{Ni}^{2+}$ (aPOP and $\mathrm{CO}^{2+}$ aPOP exhibited excellent 3,3',5,5'-tetramethylbenzidine (TMB) oxidation reaction in the presence of $\mathrm{H}_{2} \mathrm{O}_{2}$. The oxidation reaction occurred by single electron transfer, to convert colorless TMB to blue colored ox-TMB. Furthermore, the peroxidase like activity of $\mathrm{Cu}^{2+}$ (aPOP has been shown to potentially prevent TMB oxidation in the presence of ascorbic acid (AA) and dopamine (DA). Based on the inhibition effect, we achieved low detection limits of $1.4 \mathrm{mM}$ and $1 \mathrm{mM}$ for $\mathrm{AA}$ and DA through colorimetric method. To the best of our knowledge, for the first time we investigate colorimetric-based detection of both $\mathrm{AA}$ and DA. With these findings, $\mathrm{Cu}^{2+}$ aPOP has excellent catalytic activity, providing a promising prospect for biosensors and clinical fields.
\end{abstract}

\section{Introduction}

Natural enzymes are exclusive biologically active catalysts that have been utilized for comprehensive applications. Indeed, several types of mimic activities exist such as peroxidase-mimic, oxidase-mimic, catalyst-mimic, and superoxide-like activities. Among them, peroxidase-mimic activity has gained great attention due to promising properties. Peroxidases are kinds of enzymes, capable of catalyzing the oxidation of hydrogen peroxide into reactive oxygen species. Moreover, they can give good responsivity for visual detection. However, natural enzymes have certain limitations such as hydrolysis, denaturation, less stability, non-reusability, and stimuli sensitivity. ${ }^{1}$ In order to overcome the limitations of natural enzymes, nanomaterials have been shown to be preferable candidates. Previously, nanomaterials, functionalized nanomaterials, graphene oxide, graphitic carbon nitrile, carbon dots, metal-organic frameworks (MOFs), and covalent organic frameworks (COFs) were demonstrated as an alternative nanozymes. ${ }^{2-5}$ However, those are remarkable materials for peroxidase-like

Department of Chemistry, SRM Institute of Science and Technology, Kattankulathur, Chennai - 603 203, Tamil Nadu, India. E-mail: panneerp1@srmist.edu.in, panneerchem82@gmail.com; Tel: +919688538842

$\dagger$ Electronic supplementary information (ESI) available. See DOI: 10.1039/ d1ma01195b activity. Many researchers have attempted to enhance nanozyme activity with external stimuli like size, shape and surface charges and modification and compositions. Even though, they showed some limitations including less activity and stability, and high cost. $^{6-8}$ Generally, incorporation of nanoparticles into various substrate materials sufficiently enhances the peroxidase-like activity. We aim to incorporate nanoparticles into substrate materials for enhancing the peroxidase-mimic activity. In the abovementioned reports, solvothermal method, ionothermal method, and wet impregnation method were used for $\mathrm{Cu}^{2+}$ incorporation in the porous materials. However, this required harsh reaction conditions and toxic solvents and was expensive. For example, reduced graphene oxide (rGO) and graphitic carbon nitrile $\left(\mathrm{g}-\mathrm{C}_{3} \mathrm{~N}_{4}\right)$ have been used to efficiently enhance the peroxidase-like activity.,10 For example, Willner et al. reported $\mathrm{Cu}^{2+}$-modified graphene oxide $\left(\mathrm{Cu}^{2+}-\mathrm{GO}\right)$ and $\mathrm{Cu}^{2+}$-modified $\mathrm{g}-\mathrm{C}_{3} \mathrm{~N}_{4} \quad\left(\mathrm{Cu}^{2+}-\mathrm{g}-\mathrm{C}_{3} \mathrm{~N}_{4}\right)$, showing superior catalytic activity which was analyzed by chemiluminescence. ${ }^{11}$ Wang et al. described $\mathrm{Cu}^{2+}$-incorporated $\mathrm{g}-\mathrm{C}_{3} \mathrm{~N}_{4}$ having effective peroxidase-like activity, which was analyzed calorimetrically. ${ }^{12}$ Generally, porous materials have higher catalytic activity than non-porous materials due to the rich metal binding sites and high porosity.

Porous materials have multifocal advantages including affordability, stable lattice, easy storage, and multiple functionalities. ${ }^{13-16}$ However, they have some limitations 
including acid sensitivity, blockage of active sites by axial coordination in MOFs and active positions being inaccessible and diffusions in COFs. ${ }^{17,18}$ In order to overcome these limitations, copper-modified porous materials have been investigated, having enhanced peroxidase-like activity compared with unmodified porous materials. ${ }^{19}$ For instance, Li found that $\mathrm{Cu}^{2+}$-incorporated MOF (UiO-67- $\mathrm{Cu}^{2+}$ ) had remarkable lactase activity. ${ }^{20}$ Willner et al. have reported $\mathrm{Cu}^{2+}$-modified NMOF $\left(\mathrm{Cu}^{2+}-\mathrm{NMOF}\right)$ that exhibited sufficient peroxidase-mimic activity. Hence, they detected dopamine through chemiluminescence. ${ }^{21}$ Following that, Fanggui and coworkers documented a $\mathrm{Cu}^{2+}$ incorporated covalent triazine framework which oxidized $3,3^{\prime}, 5,5^{\prime}$-tetramethylbenzidine (TMB). ${ }^{22}$ According to pervious reports, $\mathrm{Cu}^{2+}$ incorporation in porous materials is an attractive way to enhance the catalytic activity.

Porous organic polymers (POPs) are well known for their unique physiochemical properties such as structural adaptively, predictability, good hydrothermal stability, large surface area, low density, and so on. ${ }^{23-26}$ POPs are promising materials for a wide range of applications including gas storage/separation, optoelectronics, organocatalysis, sensors, drug delivery, photocatalysis/ photovoltaics. ${ }^{27-31}$ Owing to the aforementioned properties, POPs are suitable for oxidation reactions but show less peroxidase-like activity. To enhance the peroxidase-like activity of POPs, we intended to incorporate transition metals. In the abovementioned reports, solvothermal method, ionothermal method, and wet impregnation method were used for $\mathrm{Cu}^{2+}$ incorporation in porous materials. However, this required harsh reaction conditions and toxic solvents and was expensive. Recently, mechanochemical synthesis of POPs has received much attention because of it being solvent free and of short reaction duration. We envisioned the incorporation of transition metal ions in POPs by mechanochemical method.

Ascorbic acid (AA) is one of the essential vitamins for human health that also is regularly used as an artificial antioxidant for food ingredients in food industries. ${ }^{32}$ Large doses of AA function as pro-anticancer agent and specifically kill colorectal cancer cells. $^{33}$ Thus, AA detection is of significance. Also, dopamine (DA) is one of the essential nutrients for the human bodies. Disordered levels of DA in the human body can lead to numerous diseases. $^{34,35}$ Therefore, detection and removal of excess DA in living systems is essential. Up to now, detection of AA and DA has been successfully carried out with instrumentation techniques including fluorescence method, electrochemical method, colorimetric method, surface plasma resonance, electro- and chemiluminescence, high-performance liquid chromatography, gas chromatography, and mass spectrometry. ${ }^{36,37}$ Among them, the colorimetric method is of great interest due to its simplicity and specificity.

Herein, we fabricated transition metal-coordinated POPs $\left(\mathrm{Ni}^{2+} @ P O P, \mathrm{Co}^{2+} @ P O P\right.$, and $\left.\mathrm{Cu}^{2+} @ P O P\right)$ through mechanochemical method. As-synthesized functional materials exhibited marked peroxidase-like activity in the presence of $\mathrm{H}_{2} \mathrm{O}_{2}$ and TMB. $\mathrm{Cu}^{2+}$ @POP shows excellent catalytic activity compared with $\mathrm{Ni}^{2+} @ P O P$ and $\mathrm{Co}^{2+} @ P O P$. In the presence of $\mathrm{H}_{2} \mathrm{O}_{2}, \mathrm{TMB}$ exhibited a strong absorption band at $652 \mathrm{~nm}$ as well as blue colour that corresponds to ox-TMB. The presence of AA and DA can inhibit oxidation of TMB and limit the colour change. This remarkable inhibition effect has been used to achieve low detection limits of $1.3 \mathrm{mM}$ and $1 \mathrm{mM}$ for AA and DA. However, pristine POP did not exhibit any catalyst activity without transition metal coordination. These phenomena allow facile colorimetric detection for AA and DA. To the best of our knowledge, for the first time we applied transition metal-coordinated POP for the dual detection of biomolecules.

\section{Materials}

Benzene-1,3,5-tricarbonyl trichloride $\left(\mathrm{C}_{9} \mathrm{H}_{3} \mathrm{O}_{3} \mathrm{Cl}_{3}\right)$, benzene-1,4diamine, triethylamine (TEA), methanol $\left(\mathrm{CH}_{3} \mathrm{OH}\right)$, sodium borohydride $\left(\mathrm{NaBH}_{4}\right)$, hydrogen peroxide $\left(\mathrm{H}_{2} \mathrm{O}_{2}\right), \mathrm{TMB}$, DA, glucose $(\mathrm{G})$, fructose (Fr), cysteine (Cy), uric acid (UA), AA, $p$-benzoquinone (PBQ), isopropyl alcohol (IPA). All chemicals were purchased from Sigma Aldrich, SRL Chemicals and Avra Chemicals and used without further purification.

\section{Characterizations}

The morphology and crystalline structure were evaluated using scanning electron microscopy (SEM, FEI Quanta FEG 200) and high-resolution transmission electron microscopy (HRTEM, JEOL, JEM, Fb-2000). Powder X-ray diffraction (PXRD) was performed using a PANalytical X'pert Pro X-ray diffractometer with $\mathrm{CuK} \alpha$ radiation. For bonding information studies, an Agilent Technologies FTIR spectrometer (USA) was used to record the Fourier transform infrared (FT-IR) spectra with the ATR mode. Thermal stability was investigated by thermogravimetric analysis (STA 2500 Thermoanalyzer).

\section{Synthesis of POP}

POP was synthesized with minor modifications according to an earlier report. $^{38}$ Benzene-1,4-diamine $(0.7332 \mathrm{~g})$ and TEA $(1.9057 \mathrm{~g})$ were dissolved in $30 \mathrm{ml}$ of DCM in a $100 \mathrm{ml}$ round bottom flask. Benzene-1,3,5-tricarbonyl trichloride $(1.0 \mathrm{~g})$ dissolved in $30 \mathrm{ml}$ of DCM was added under ice-cold conditions to the reaction mixture. It is interesting to note that with a few drops of $\mathrm{C}_{9} \mathrm{H}_{3} \mathrm{O}_{3} \mathrm{Cl}_{3}$ added into reaction mixture, immediately a semi-solid was formed. The reaction was continued for a further 12 hours for complete conversion of POP. The obtained solid was washed with distilled water followed by methanol and acetone several times. The obtained material was dried overnight at room temperature and, finally, olive-colored POP was collected.

\section{Synthesis of transition metal-coordinated POP ( $\left.\mathbf{M}^{2+} @ P O P\right)$}

The $\mathrm{M}^{2+} @ P O P$ systematic synthetic scheme is depicted in Scheme 1. Typically, $100 \mathrm{mg}$ of prepared POP was placed in a mortar. Subsequently, $5 \mathrm{mg}$ of metal precursor $\left(\mathrm{Ni}(\mathrm{OAc})_{2}\right.$, or $\mathrm{Co}(\mathrm{OAc})_{2}$, or $\left.\mathrm{Cu}(\mathrm{OAc})_{2}\right)$ with a drop of TEA was added. The mixture was ground for 15 minutes and the olive color changed to purple color for $\mathrm{Cu}^{2+}$ ions. Moreover, the obtained solid was washed with distilled water several times. Further, the product was dried at $60{ }^{\circ} \mathrm{C}$ in a hot-air oven for 12 hours. Finally, the 
transition metal-coordinated POPs $\left(\mathrm{Ni}^{2+} @ \mathrm{POP}, \mathrm{Co}^{2+} @ \mathrm{POP}\right.$ and $\mathrm{Cu}^{2+}$ @POP) were collected.

\section{Results and discussion}

Herein, $\mathrm{M}^{2+} @ P O P s$ were synthesized by a mechanochemical method. The $\mathrm{M}^{2+} @ P O P$ synthetic route is systematically depicted in Scheme 1. For metal ion incorporation, microwave, solvothermal, and ion-thermal methods were developed. ${ }^{39,40}$ Typically, benzene-1,3,5-tricarbonyl trichloride and benzene-1,4-diamine have been coordinated in the presence of TEA at room temperature. Hence, POP was formed through nucleophile addition/ elimination reaction. Subsequently, $\mathrm{Ni}^{2+}, \mathrm{Co}^{2+}, \mathrm{Cu}^{2+}$ and POP were ground mechanochemically. Thereby, transition metal ions were coordinated to POP, and thus $\mathrm{Cu}^{2+} @ \mathrm{POP}, \mathrm{Ni}^{2+} @ \mathrm{POP}$ and $\mathrm{Co}^{2+} @$ POP were synthesized.

Initially, the synthesized $\mathrm{Ni}^{2+} @ \mathrm{POP}, \mathrm{Co}^{2+} @ \mathrm{POP}$, and $\mathrm{Cu}^{2+} @$ POP morphologies were ascertained by SEM and TEM imaging and the results are shown in Fig. 1. As seen in Fig. 1a, the obtained POPs have sphere-like morphology and are agglomerated. Also, SEM mapping and EDS analysis confirmed the existence of C, N, and O elements (Fig. S2 and S7a, ESI $\dagger$ ). ${ }^{41}$ Moreover, TEM images also clearly indicate the as-prepared POPs have a spherical shape and polymeric nature, as displayed in Fig. $1 \mathrm{~b}$ and Fig. S1 (ESI $\dagger$ ). SEM images of the $\mathrm{Cu}^{2+}$ coordinated POP $\left(\mathrm{Cu}^{2+} @ \mathrm{POP}\right)$ exhibited a slightly collapsed sphere-like morphology (Fig. 1c and d). It is interesting to note that the collapsed spherical shape is due to coordination with $\mathrm{Cu}^{2+}$ ions. As well, SEM mapping and EDS undoubtedly confirmed $\mathrm{C}, \mathrm{N}, \mathrm{O}$, and $\mathrm{Cu}^{2+}$ elements were present (Fig. S3 and S7b, ESI $\dagger$ ). Moreover, TEM images also ascertained a collapse in spherical shape, mainly due to incorporation $\mathrm{Cu}^{2+}$ in the POP. The HRTEM images show small particles spread over the POP as displayed in Fig. 1e and f. Similarly, SEM images of $\mathrm{Ni}^{2+} @ P O P$ and $\mathrm{Co}^{2+} @ P O P$ are shown in Fig. S4a and S53b (ESI $\dagger$ ). EDS and SEM mapping undoubtedly confirmed the existence of $\mathrm{C}, \mathrm{N}, \mathrm{O}$, and $\mathrm{Ni}^{2+}$ elements for $\mathrm{Ni}^{2+} @ \mathrm{POP}$, and $\mathrm{C}, \mathrm{N}, \mathrm{O}$, and $\mathrm{Co}^{2+}$ elements for $\mathrm{Co}^{2+}$ @POP (Fig. S4, S5 and S7, ESI $\dagger$ ).

Following the morphological study, prepared POP, $\mathrm{Ni}^{2+}$ @ POP, $\mathrm{Co}^{2+} @ \mathrm{POP}$, and $\mathrm{Cu}^{2+} @ \mathrm{POP}$ were analyzed by FT-IR
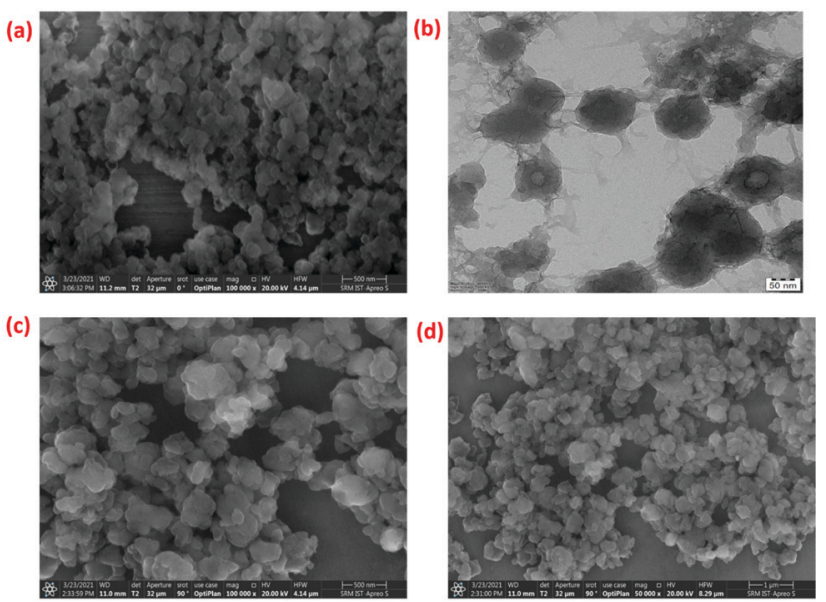

(e)
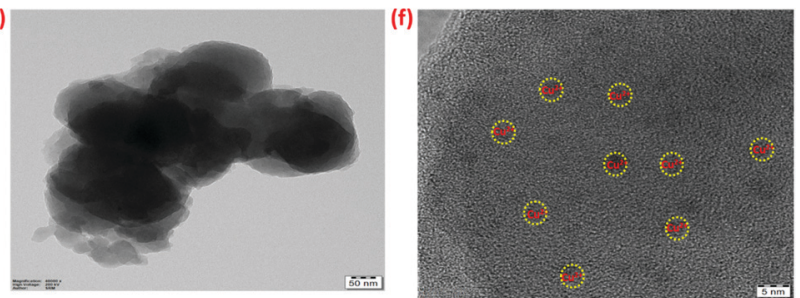

Fig. 1 (a) SEM image of POP; (b) TEM image of POP; (c and d) SEM images of $\mathrm{Cu}^{2+}\left(\mathrm{PPOP} ;\right.$ and (e and f) TEM images of $\mathrm{Cu}^{2+} @$ POP.

spectroscopy, and the results are displayed in Fig. 2. Typically, absorption bands appeared at $1645 \mathrm{~cm}^{-1}$ and $1661 \mathrm{~cm}^{-1}$ associated with amide $\mathrm{C}=\mathrm{O}$ stretching frequency (amide-I band). The $\mathrm{N}-\mathrm{H}$ band was observed at $1511 \mathrm{~cm}^{-1}$ corresponding to bending frequency of amide-II band; at the same time $\mathrm{N}-\mathrm{H}$ and $\mathrm{C}-\mathrm{N}$ bonding interaction bands presented at 1252 and $1312 \mathrm{~cm}^{-1}$. Notably, a broad band appeared at $3307 \mathrm{~cm}^{-1}$ associated with $\mathrm{N}-\mathrm{H}$ stretching frequency, this result revealing POP had been formed. Notably, $701 \mathrm{~cm}^{-1}$ peak was not observed that corresponds to acid chloride, which emphasizes that acid chloride was completely converted to POP and this well matched with an earlier report. ${ }^{38}$ After confirming the formation of POP, transition metal ions ( $\mathrm{M}=$ $\mathrm{Ni}^{2+}, \mathrm{Co}^{2+}, \mathrm{Cu}^{2+}$ ) were coordinated with POP through a mechanochemical method. As a result, the $\mathrm{N}-\mathrm{H}$ bending band was

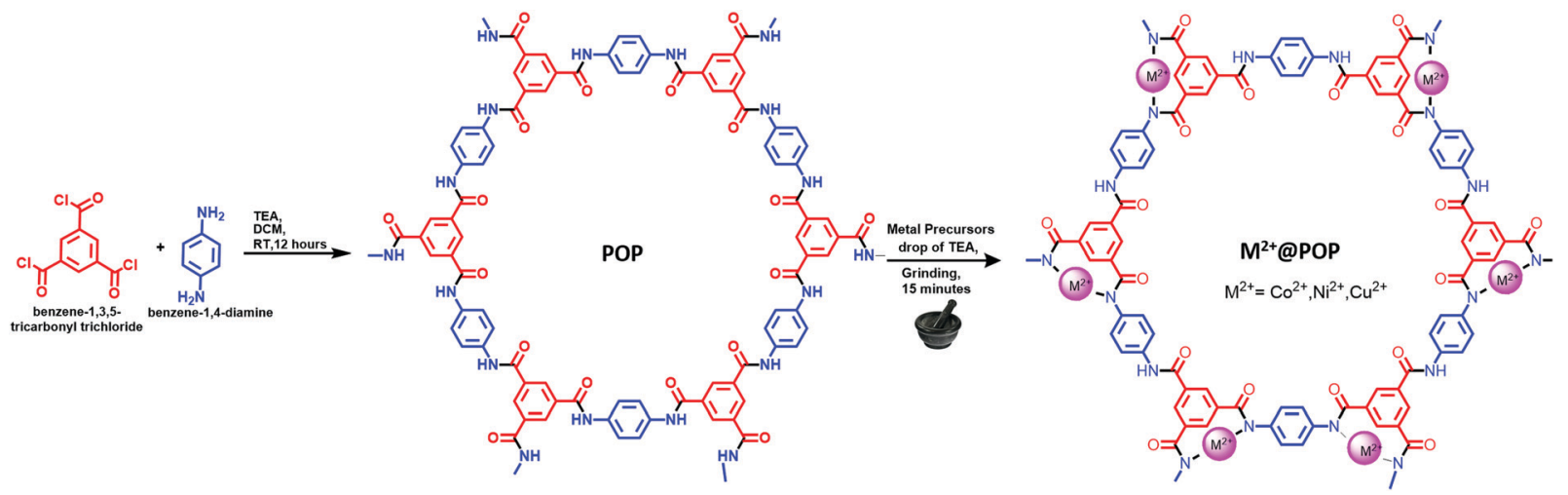

Scheme 1 Schematic illustration for synthesis of $\mathrm{M}^{2+}$ (aPOP. 


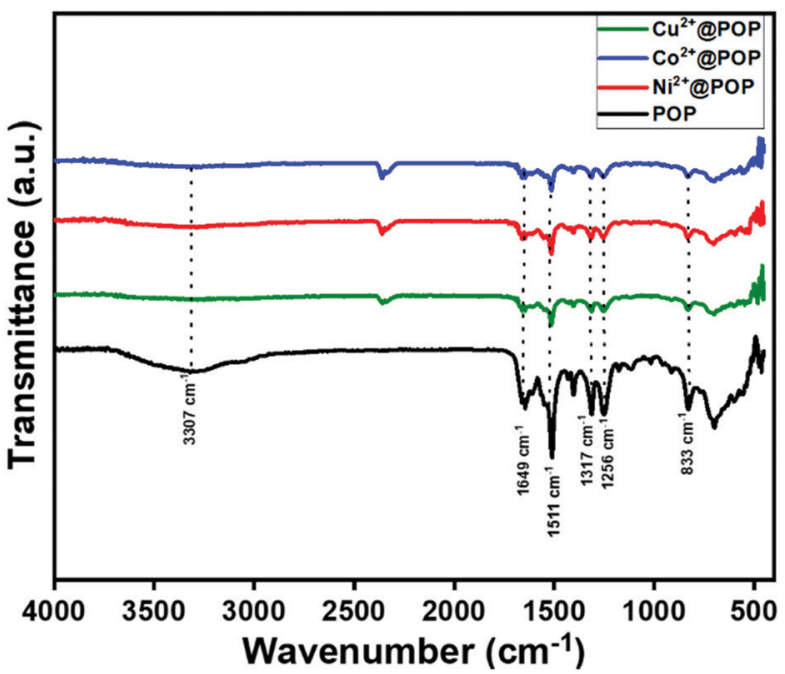

Fig. 2 FT-IR spectra of POP, $\mathrm{Ni}^{2+}$ aPOP, $\mathrm{Co}^{2+}$ aPOP, and $\mathrm{Cu}^{2+}$ aPOP

drastically reduced, that reduction being due to the coordination between $\mathrm{Ni}^{2+}, \mathrm{Co}^{2+}$ and $\mathrm{Cu}^{2+}$ and electron-rich nitrogen group of POP. The FT-IR results clearly indicate the formation of POP and $\mathrm{Ni}^{2+} @ \mathrm{POP}, \mathrm{Co}^{2+} @ \mathrm{POP}$, and $\mathrm{Cu}^{2+} @ \mathrm{POP}$.

Following the FT-IR analysis, the as-synthesized materials (POP, $\mathrm{Ni}^{2+} @ \mathrm{POP}, \mathrm{Co}^{2+} @ \mathrm{POP}$, and $\left.\mathrm{Cu}^{2+} @ \mathrm{POP}\right)$ were investigated by PXRD as displayed in Fig. 3. As depicted in Fig. 3, $2 \theta$ peaks were located at $28^{\circ}$ and $43^{\circ}$, which are associated with repeating units and $\pi-\pi$ interaction. This result indicates that amorphous POP was formed. Moreover, with transition metal ion incorporation into POP, discrete diffraction peaks at $44.3^{\circ}$ corresponding to 111 plane of metallic peaks for $\mathrm{Ni}^{2+} @ \mathrm{POP}, \mathrm{Co}^{2+} @ \mathrm{POP}$, and $\mathrm{Cu}^{2+} @ \mathrm{POP}$ were not detected. Interestingly, repeating units were prominent due to the coordination with metal ions. This result reveals successful coordination between amine groups of POP and metal ions. In addition, note that $\mathrm{Cu}_{0}$ and $\mathrm{Cu}_{x} \mathrm{O}$ are not observed by this method; also, $\mathrm{Cu}^{2+}$ is dominant in $\mathrm{Cu}^{2+} @ \mathrm{POP}^{22}$ Additionally, $\mathrm{Cu}^{2+}$ presence was clarified by SEM mapping and

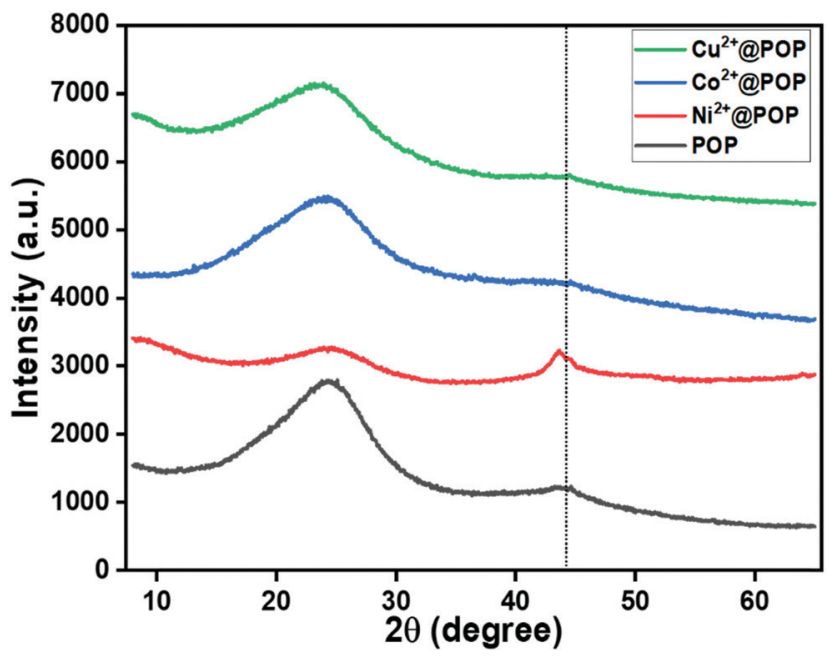

Fig. 3 PXRD patterns of POP, $\mathrm{Ni}^{2+}$ aPOP, $\mathrm{Co}^{2+} \mathrm{aPOP}$, and $\mathrm{Cu}^{2+} \mathrm{aPOP}$.
UV-visible spectra, as we discuss in more detail below. According to the diffraction result, the formation of amide-functionalized POP and $\mathrm{Cu}^{2+} @ \mathrm{POP}, \mathrm{Ni}^{2+} @ \mathrm{POP}$, and $\mathrm{Co}^{2+} @ \mathrm{POP}$ was confirmed.

UV-visible spectra were examined to explore the optical absorption properties of prepared POP, $\mathrm{Ni}^{2+} @ \mathrm{POP}, \mathrm{Co}^{2+} @ \mathrm{POP}$, and $\mathrm{Cu}^{2+} @$ POP. As shown in Fig. 4a, the spectrum of pristine POP had a characteristic absorption band positioned at $350 \mathrm{~nm}$ due to the $\mathrm{n}-\pi^{*}$ transition of amide group of POP. However, the $\mathrm{n}-\pi^{*}$ transition band shifted to 371,372 and $379 \mathrm{~nm}$ for $\mathrm{Ni}^{2+} @ P O P, \mathrm{Co}^{2+} @ P O P$, and $\mathrm{Cu}^{2+} @ P O P$, respectively. The shift reveals coordination between POP and $\mathrm{Co}^{2+}, \mathrm{Ni}^{2+}$, and $\mathrm{Cu}^{2+}$. These results confirmed that $\mathrm{Co}^{2+}, \mathrm{Ni}^{2+}$, and $\mathrm{Cu}^{2+}$ had been successfully coordinated with POP. Subsequently, the thermal stability of obtained POP, $\mathrm{Ni}^{2+} @ \mathrm{POP}, \mathrm{Co}^{2+} @ \mathrm{POP}$, and $\mathrm{Cu}^{2+} @$ POP was appraised by TGA measurement, the results being shown in Fig. 4b. Initially, loss of surface-adsorbed $\mathrm{H}_{2} \mathrm{O}$ showed a weight decrease up to $7 \%, 5 \%, 3 \%$ and $5 \%$ for POP, $\mathrm{Ni}^{2+} @ \mathrm{POP}, \mathrm{Co}^{2+} @ \mathrm{POP}$, and $\mathrm{Cu}^{2+} @ \mathrm{POP}$, respectively. Asprepared POP had sustainable thermal stability up to $300{ }^{\circ} \mathrm{C}$; coordination with corresponding metal ions increased the stability to more than $350{ }^{\circ} \mathrm{C}$ for $\mathrm{Ni}^{2+} @ \mathrm{POP}, \mathrm{Co}^{2+} @ \mathrm{POP}$, and $\mathrm{Cu}^{2+} @$ POP. The TGA results also clearly indicated that transition metal ions successfully coordinated with POP and the resulting materials have excellent thermal stability.

Furthermore, chemical composition and oxidation state of POP and $\mathrm{Cu}^{2+} @ P O P$ were extensively studied by X-ray photoemission spectroscopy (XPS). The wide range spectra clearly indicate $\mathrm{C}, \mathrm{N}$, and $\mathrm{O}$ for $\mathrm{POP}^{22}$ and $\mathrm{Cu}, \mathrm{C}, \mathrm{N}$, and $\mathrm{O}$ for $\mathrm{Cu}^{2+}$ @POP, as shown in Fig. 5a. As seen in Fig. 5b, showing the high-resolution spectrum of $\mathrm{Cu}^{2+}$ with deconvolution, $\mathrm{Cu}^{2+}$ shows exquisite major characteristic peaks at 933.5, 935.5 and $953.6 \mathrm{eV}^{42}$ These results confirmed that $\mathrm{Cu}^{2+}$ was successfully coordinated into POP via mechanochemical method. Furthermore, the high-resolution spectra of $\mathrm{N} 1 \mathrm{~s}$ and $\mathrm{O}$ 1s clearly indicate coordination between $\mathrm{Cu}^{2+}$ and amine group of POP. ${ }^{43}$ In the N 1s deconvoluted spectrum of POP, peaks appeared at 399.7 and $400.2 \mathrm{eV}$ corresponding to $\mathrm{C}-\mathrm{N}$ and free $\mathrm{N}-\mathrm{H}$ as shown in Fig. $5 \mathrm{c}$. It is interesting to note that for POP after coordination with $\mathrm{Cu}^{2+}$, a new peak appeared at $405.5 \mathrm{eV}$ associated with $\mathrm{N}-\mathrm{Cu}$ coordination. From this observation, we confirmed the $\mathrm{N}$ atom coordinated with $\mathrm{Cu}^{2+}$ to form a $\mathrm{Cu}^{2+}$-incorporated POP. Likewise, O 1s spectra indicate non-covalent interaction. In the high-resolution $\mathrm{O} 1 \mathrm{~s}$ spectrum, peaks appeared at 531.3, 532.4, and $533.2 \mathrm{eV}$ which are associated with $\mathrm{C}=\mathrm{O}, \mathrm{C}-\mathrm{O}$ and adsorbed $\mathrm{O}_{2}$. Subsequently, after coordination with $\mathrm{Cu}^{2+}$, these slightly shifted to 531.6, 532.7 and $533.5 \mathrm{eV}$, emphasizing oxygen atom was involved though non-covalent interaction (Fig. 5d). The C 1s spectra are shown in Fig. S3 (ESI $\dagger$ ). According to these XPS spectra, we concluded that $\mathrm{Cu}^{2+}$ was coordinated with POP.

\section{Investigation of a peroxidase-like activity of $\mathrm{M}^{2+} @ P O P$}

Horseradish peroxidase (HRP)-like activity is naturally found for enzymes extracted from plants, which are widely used in various applications such as biosensors (detection of $\mathrm{H}_{2} \mathrm{O}_{2}$, glucose, DNA, and RNA), biocatalysis and cancer treatment, even though HRP has some limitations. To replace HRP, 

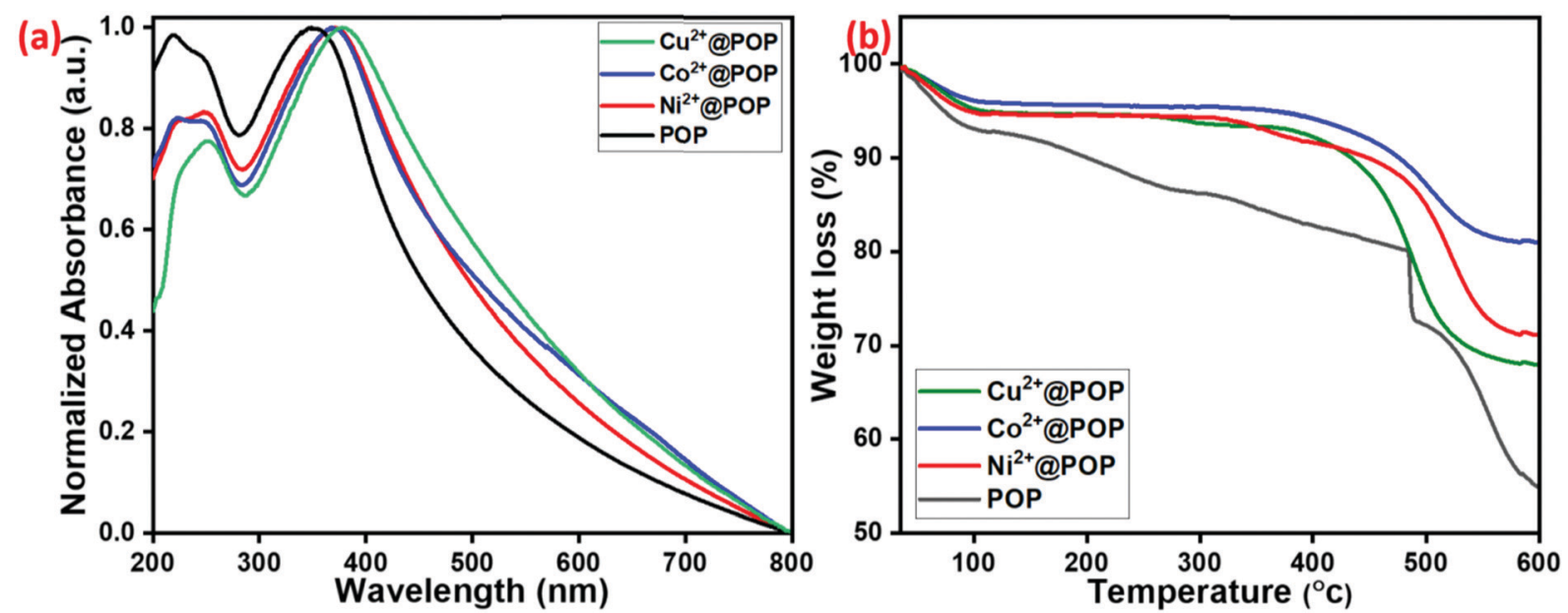

Fig. 4 (a) UV-visible spectra and (b) TGA curves of POP, $\mathrm{Ni}^{2+}\left(\mathrm{aPOP}, \mathrm{Co}^{2+} \mathrm{aPOP}\right.$, and $\mathrm{Cu}^{2+} \mathrm{aPOP}$.

prepared POP, $\mathrm{Cu}^{2+} @ \mathrm{POP}, \mathrm{Ni}^{2+} @ \mathrm{POP}$ and $\mathrm{Co}^{2+} @ \mathrm{POP}$ have been employed for their peroxidase-like activity. The oxidation reaction analyzed was that of TMB to ox-TMB in the presence of $\mathrm{H}_{2} \mathrm{O}_{2}$, as illustrated in Fig. 6a. The oxidation of TMB is mainly of three types: one-electron transfer, two-electron transfer and mixture of one- and two-electron transfer process. Consequently, one can obtain a blue, green and yellow color, respectively. For example, NPs catalyze the oxidation reaction of TMB in the presence of $\mathrm{H}_{2} \mathrm{O}_{2}$. Thus, POP, $\mathrm{Cu}^{2+}$ @POP, $\mathrm{Ni}^{2+} @ P O P$ and $\mathrm{Co}^{2+} @ P O P$ were investigated for their peroxidase-mimicking function. As seen in Fig. 6a, the mixture of TMB, $\mathrm{H}_{2} \mathrm{O}_{2}$ and $\mathrm{Cu}^{2+} @ P O P$ gives intense blue color as well as a characteristic absorption peak appearing at $652 \mathrm{~nm}$, which corresponds to oxidation of TMB (ox-TMB). In contrast, TMB/ $\mathrm{H}_{2} \mathrm{O}_{2}, \mathrm{Cu}^{2+} @ \mathrm{POP} / \mathrm{TMB}$ and $\mathrm{Cu}^{2+} @ \mathrm{POP} / \mathrm{H}_{2} \mathrm{O}_{2}$ do not exhibit any color change or absorption peak. When the concentration of $\mathrm{H}_{2} \mathrm{O}_{2}$ is increased, the absorption peak is intensified. According to the result, $\mathrm{Cu}^{2+} @$ POP operated thorough the one-electron transfer process. Moreover, the optical photographs too clearly displayed color appearing for $\mathrm{Cu}^{2+} @ \mathrm{POP}$ in the presence of TMB and $\mathrm{H}_{2} \mathrm{O}_{2}$ solution (inset of Fig. 6a). According to the XPS result, $\mathrm{Cu}^{2+} @ \mathrm{POP}$ has a trinuclear copper center that contains $\mathrm{Cu}^{2+}$ and $\mathrm{Cu}^{+}$in two oxidation states. This particular type of copper center is similar to that of $\mathrm{Cu}^{2+}-\mathrm{Cu}^{2+}$ analogues. During the oxidation of TMB, $\mathrm{Cu}^{2+}-\mathrm{Cu}^{2+}$ was reduced to $\mathrm{Cu}^{+}-\mathrm{Cu}^{+}$, so that $\mathrm{Cu}^{2+} @$ POP oxidized TMB in the presence of $\mathrm{H}_{2} \mathrm{O}_{2}$. Moreover, $\mathrm{Cu}^{2+}$ atoms were uniformly dispersed in $\mathrm{Cu}^{2+}$ @POP, which was not the case for $\mathrm{Cu}_{0}$ and $\mathrm{Cu}_{x} \mathrm{O}$. Impressively, $\mathrm{Cu}^{2+} @ P O P$ showed a high peroxidase-mimic activity compared to POP, $\mathrm{Ni}^{2+} @ P O P$ and $\mathrm{Co}^{2+} @ P O P$. The oxidation of TMB by $\mathrm{Cu}^{2+} @ P O P$ can produce a blue color corresponding to the single-electron transfer process. According to that, $\mathrm{Cu}^{2+}$ @POP shows higher peroxidase-mimic activity compared with POP, $\mathrm{Ni}^{2+}$ @POP and $\mathrm{Co}^{2+}$ @POP (Fig. 6b). Among them, $\mathrm{Cu}^{2+} @ \mathrm{POP}$ displayed a more intense color than $\mathrm{Ni}^{2+} @ \mathrm{POP}$ and $\mathrm{Co}^{2+} @ \mathrm{POP}$ (optical images shown in the inset of Fig. 6b). From this result, we confirmed the prepared $\mathrm{Cu}^{2+} @ \mathrm{POP}$ has superior catalytic activity.

\section{Optimization conditions}

Peroxidase-like activity of $\mathrm{Cu}^{2+} @ P O P$ was exhibited as characteristic absorption peaks as well as naked-eye color change. Moreover, some external factors affected catalytic activity, including $\mathrm{pH}$, time, and concentration of $\mathrm{TMB} / \mathrm{Cu}^{2+} @ \mathrm{POP}$. Hence, optimized $\mathrm{pH}$ was found via use of constant quantity of $\mathrm{H}_{2} \mathrm{O}_{2}, \mathrm{TMB}$ and $\mathrm{Cu}^{2+} @ \mathrm{POP}$ at different pH (3 to 10), from which respective absorption peaks with intense blue color appeared. Among them, $\mathrm{pH}=4$ gave the best catalytic activity for oxidation of TMB (Fig. 7a) and also a digital image clearly shows the color change depending on the $\mathrm{pH}$ (inset of Fig. 7a). Then, the time-dependent oxidation process was investigated, as displayed in Fig. $7 \mathrm{~b}$. We also estimated the concentration of $\mathrm{Cu}^{2+}$ @POP for oxidation of TMB at optimized pH and time. As seen in Fig. 7c, 10-100 $\mu \mathrm{g}$ of $\mathrm{Cu}^{2+} @$ POP was used for the oxidation of TMB, other parameters kept constant. The timedependent absorption intensity was recorded at $652 \mathrm{~nm}$. The intensity of the $652 \mathrm{~nm}$ peak gradually increased up to $100 \mu \mathrm{g}$ of $\mathrm{Cu}^{2+} @$ POP. Hence, $100 \mu \mathrm{g}$ of $\mathrm{Cu}^{2+} @$ POP showed the best catalytic activity. The same procedure as mentioned above was followed for TMB optimization with various concentrations; according to this result, $90 \mathrm{mM}$ TMB exhibited the highest activity (Fig. 7d).

\section{Kinetics study}

To quantify the peroxidase-like activity of $\mathrm{Cu}^{2+} @ \mathrm{POP}$, a steadystate kinetic study via catalytic behavior with TMB and $\mathrm{H}_{2} \mathrm{O}_{2}$ was employed. The Michaelis-Menten curves obtained concentration of TMB and $\mathrm{H}_{2} \mathrm{O}_{2}$ as a substrate. Moreover, MichaelisMenten curves (Fig. S7a and c, ESI $\dagger$ ) and Lineweaver-Burk plots (Fig. S7b and d, ESI $\dagger$ ) could be obtained for TMB and $\mathrm{H}_{2} \mathrm{O}_{2}$ within certain ranges of concentration, respectively. Then, we fitted the Lineweaver-Burk plot to calculate the MichaelisMenten constant $\left(K_{\mathrm{m}}\right)$ and maximal initial velocity $(V)$ of the catalytic reaction involving Cu-HMT. The $K_{\mathrm{m}}$ value of $\mathrm{Cu}^{2+}$ @ POP for the substrate $\mathrm{H}_{2} \mathrm{O}_{2}$ and TMB was $1.1343 \mathrm{mM}$ and $0.79 \mathrm{mM}$. Moreover, the calculated $V_{\max }$ of these two systems were $214.8 \times$ 
(a)
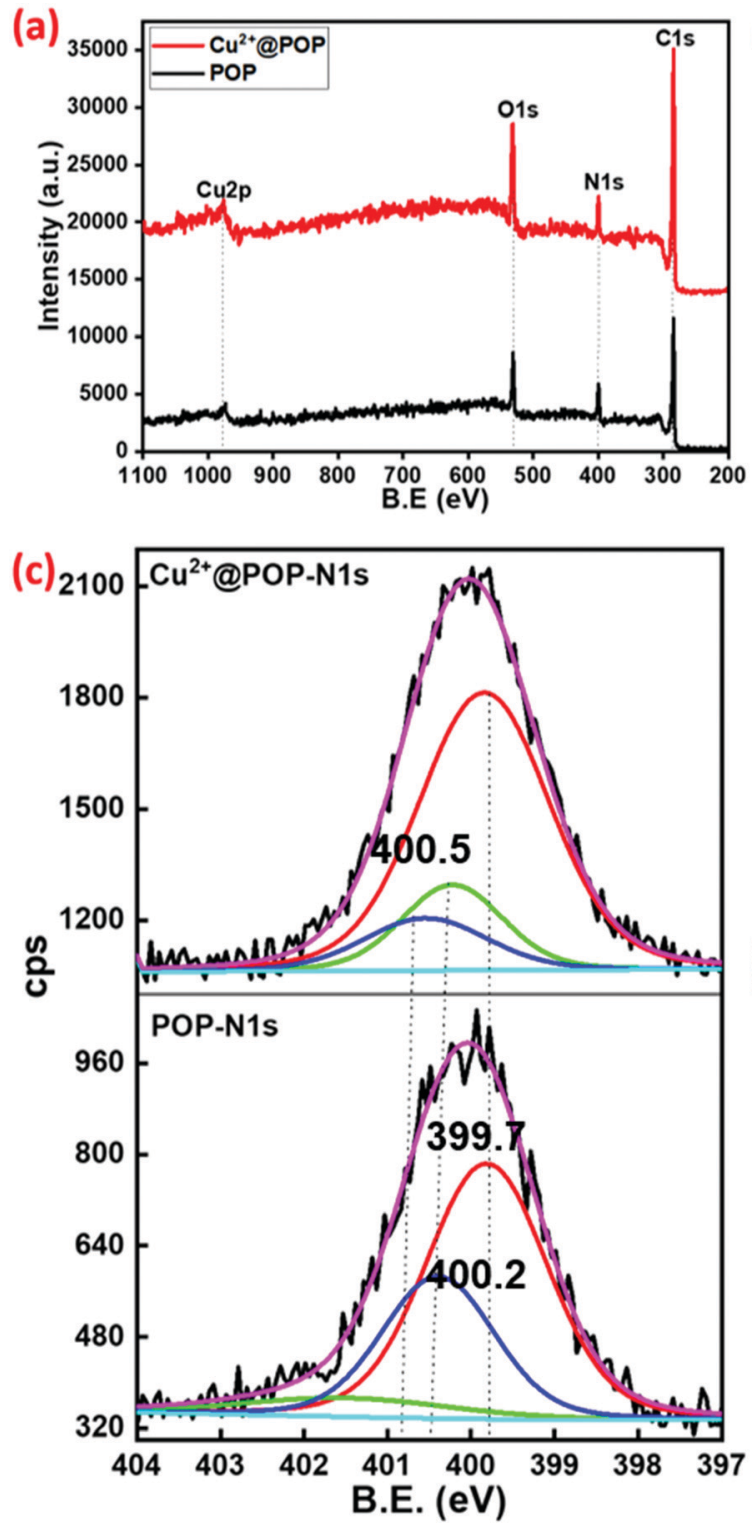

(b)
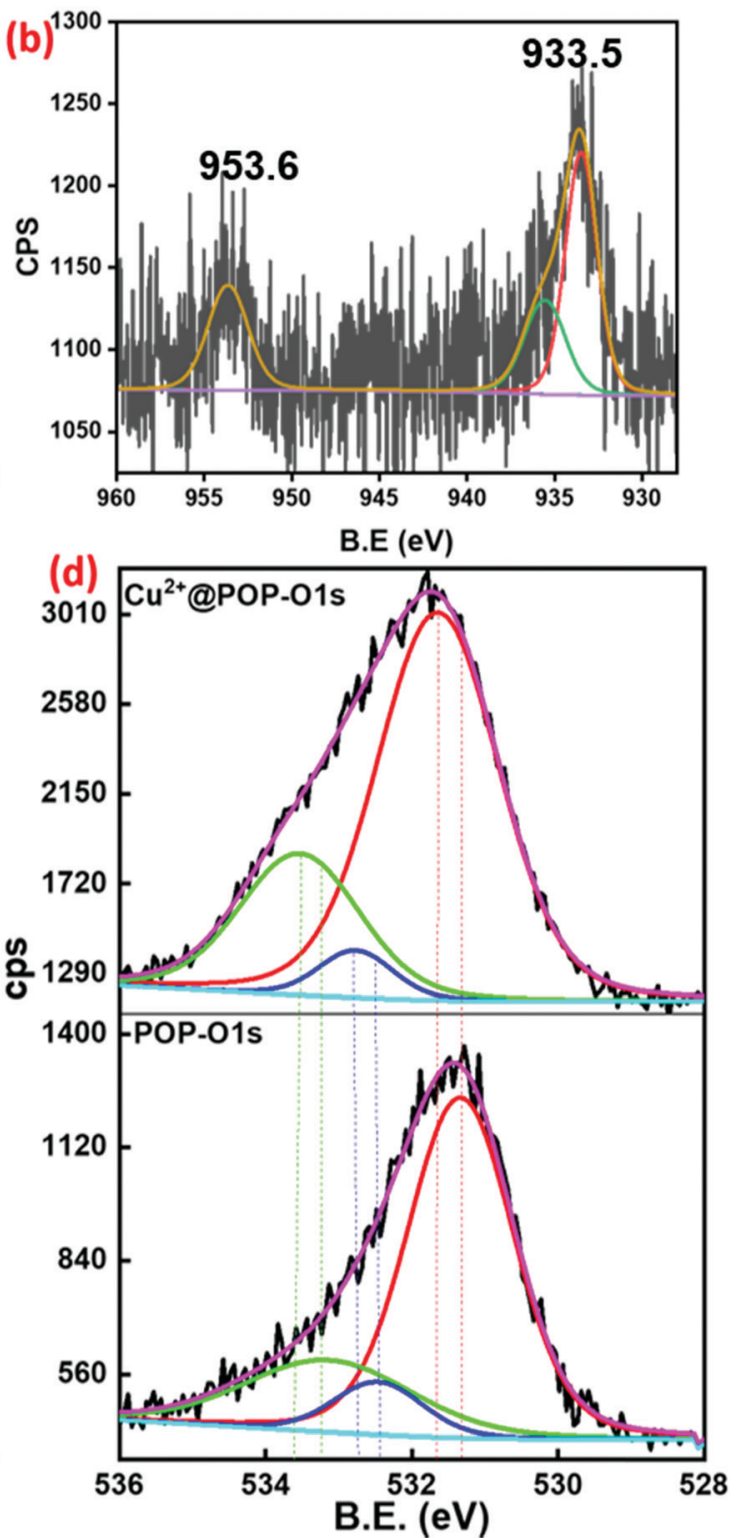

Fig. 5 (a) Survey spectra of prepared POP and $\mathrm{Cu}^{2+}$ (aPOP. (b) High-resolution spectrum of $\mathrm{Cu}_{2 p}$ of $\mathrm{Cu}^{2+}$ (aPOP. (c and d) Deconvoluted $\mathrm{N}$ 1s and $\mathrm{O}$ 1s spectra before and after coordination with $\mathrm{Cu}^{2+}$.

$10^{8} \mathrm{M}^{-1} \mathrm{~s}$ and $3.5 \times 10^{8} \mathrm{M}^{-1} \mathrm{~s}$, respectively. According to the results, we conclude that as-prepared $\mathrm{Cu}-\mathrm{HMT}$ has superior binding affinity towards $\mathrm{H}_{2} \mathrm{O}_{2}$ and $\mathrm{TMB}$ that enhanced the peroxidase-like activity.

To further investigate the catalytic mechanism of $\mathrm{Cu}^{2+}$ @POP-induced peroxidase-like activity, a series of scavengers were used to scavenge the possible reactive oxygen species (ROS) during the catalytic reaction, including hydroxyl radicals $\left({ }^{\circ} \mathrm{OH}\right)$, superoxide anions $\left({ }^{\bullet} \mathrm{O}_{2}{ }^{-}\right)$, and holes $\left(\mathrm{h}^{+}\right)$. By adding IPA that scavenges hydroxyl radicals $\left({ }^{\bullet} \mathrm{OH}\right)$, no obvious color change or characteristic absorption band at $652 \mathrm{~nm}$ was seen, which reveals that ${ }^{\bullet} \mathrm{OH}$ is not a major contributing ROS for oxidation of TMB. The result is shown in Fig. 8a. The catalytic activity was not obviously inhibited by EDTA, indicating that holes $\left(\mathrm{h}^{+}\right)$also are not major contributors. Addition of $p$-benzoquinone to ox-TMB solution exhibits an apparent inhibition effect on oxidation of TMB, confirming that superoxide anions $\left({ }^{\bullet} \mathrm{O}_{2}{ }^{-}\right)$are ROS responsible for the oxidation TMB. The NBT analysis, which have absorbance band exhibited at $550 \mathrm{~nm}$ during the in the presence of riboflavin and light (control). Our case addition of $\mathrm{Cu}^{2+} @ \mathrm{POP}$ and $\mathrm{H}_{2} \mathrm{O}_{2}$ existence of absorption band at $550 \mathrm{~nm}$ in the presence of NBT presence. Bare NBT exhibits an absorption band with low intensity. After incubation of $\mathrm{Cu}^{2+}$ @POP and $\mathrm{H}_{2} \mathrm{O}_{2}$, the absorption band at $550 \mathrm{~nm}$ has increased because of production of superoxide ions $\left({ }^{\bullet} \mathrm{O}_{2}{ }^{-}\right)$. According to Fig. 8b, superoxide ions $\left({ }^{\bullet} \mathrm{O}_{2}{ }^{-}\right)$are confirmed as the major ROS for oxidation of TMB. There appeared no reduction peak for a bare glass carbon electrode. After modifying with $\mathrm{Cu}^{2+} @ P O P$, the electrode shows a strong reduction peak at $-0.5 \mathrm{eV}$, which verified the reduction of $\mathrm{H}_{2} \mathrm{O}_{2}$, similar to a previous report. This result emphasizes the 

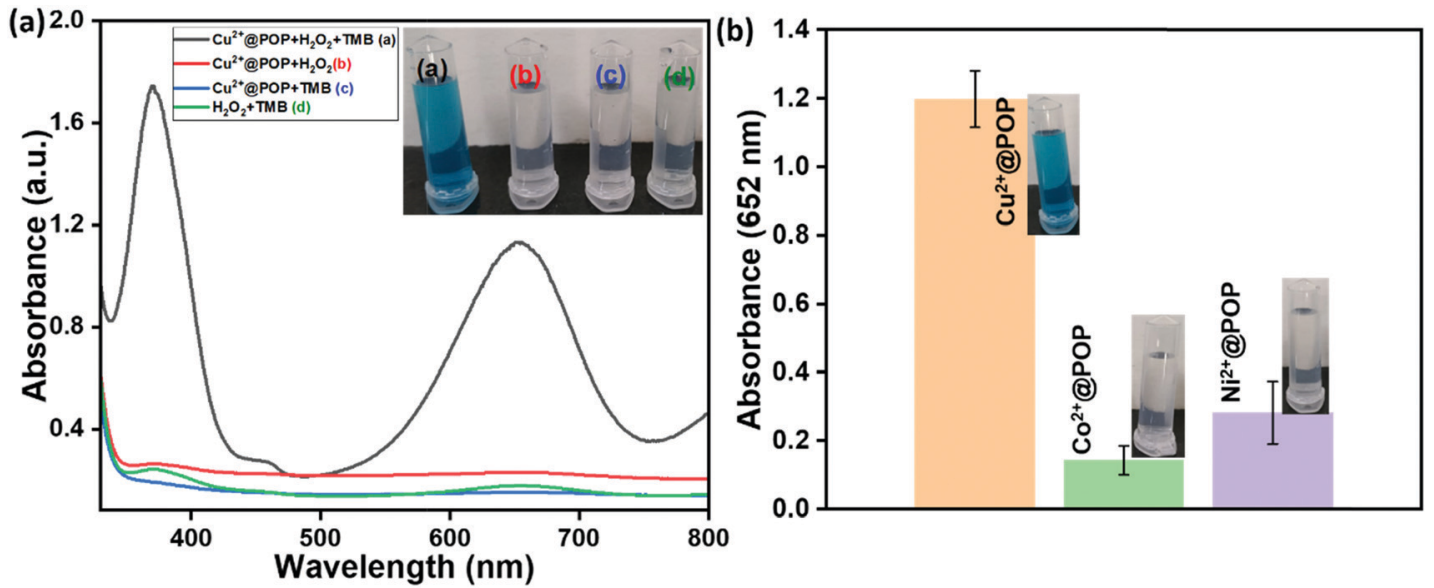

Fig. 6 (a) UV-visible spectra of $\mathrm{Cu}^{2+}$ (aPOP for oxidation of TMB in the presence of $\mathrm{H}_{2} \mathrm{O}_{2}$ and optical image shown as inset. (b) Oxidation efficiency of TMB with $\mathrm{Cu}^{2+} \mathrm{aPOP}, \mathrm{Co}^{2+} \mathrm{aPOP}$ and $\mathrm{Ni}^{2+} \mathrm{aPOP}$, with color changes shown in inset optical images.
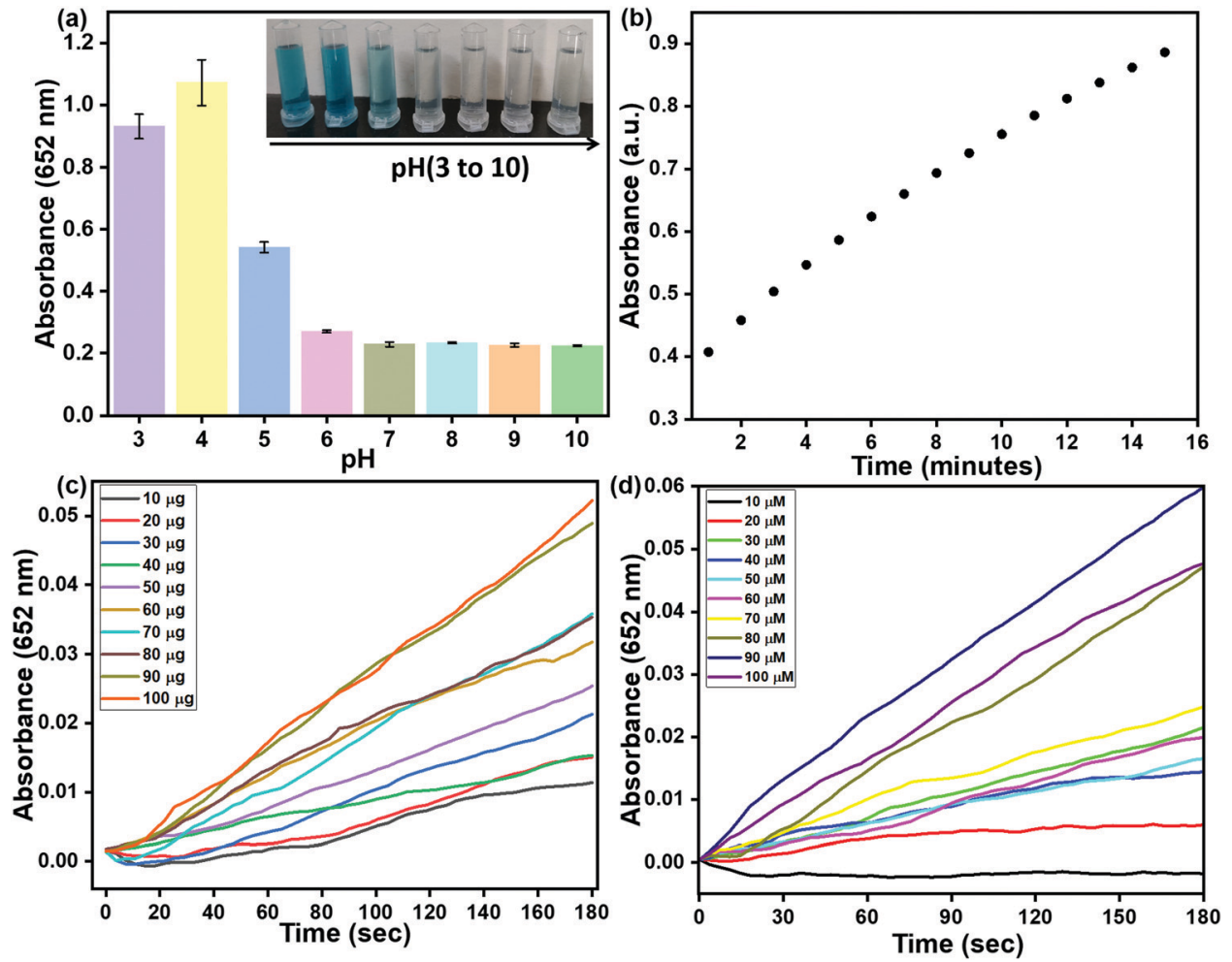

Fig. 7 Optimization experiments: (a) pH; (b) time-dependent absorption intensity; (c) different concentrations of TMB; (d) various quantities of $\mathrm{Cu}^{2+} \mathrm{aPOP}$

peroxidase-mimic reaction through superoxide. The results reveal the ability of $\mathrm{Cu}^{2+} @ P O P$ to transfer electrons between electron donor and acceptor, referring to electrode surface and $\mathrm{H}_{2} \mathrm{O}_{2}$, respectively (Fig. S10, ESI $\dagger$ ).

\section{Detection of $\mathrm{H}_{2} \mathrm{O}_{2}$ and $\mathrm{AA}$}

The determination of $\mathrm{H}_{2} \mathrm{O}_{2}$ was analyzed by oxidation of TMB with synthesized $\mathrm{Cu}^{2+}$ @POP, as shown in Fig. S8 (ESI $\dagger$ ). As mentioned above, the optimum reaction conditions for $\mathrm{H}_{2} \mathrm{O}_{2}$ analysis were found from the above mentioned experiments.
With increasing concentration of $\mathrm{Cu}^{2+}$ @POP and TMB in the presence of different concentrations of $\mathrm{H}_{2} \mathrm{O}_{2}$, there is a dramatically increased absorbance at $652 \mathrm{~nm}$; hence absorbance was directly proportional to the concentration. The ROS produced can oxidize TMB which turns into a blue color. Moreover, the absorption band and color emphasize the one-electron transfer process. The intensity of the absorption band at $652 \mathrm{~nm}$ changes relative to the concentration of $\mathrm{H}_{2} \mathrm{O}_{2}$ (Fig. S8 (ESI $\dagger$ ) insert shows optical images of different concentrations of $\mathrm{H}_{2} \mathrm{O}_{2}$ in the reaction system). Besides, the peroxidase-like activity of $\mathrm{Cu}^{2+} @ P O P$ and the 
(a)

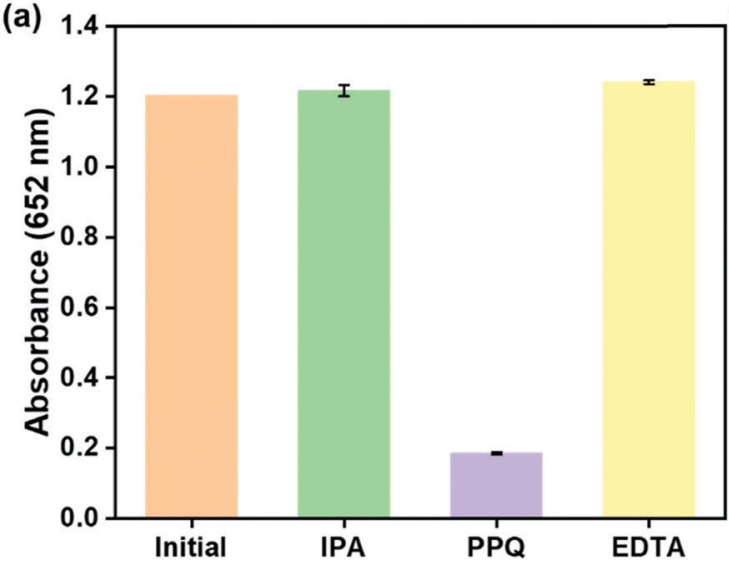

(b)

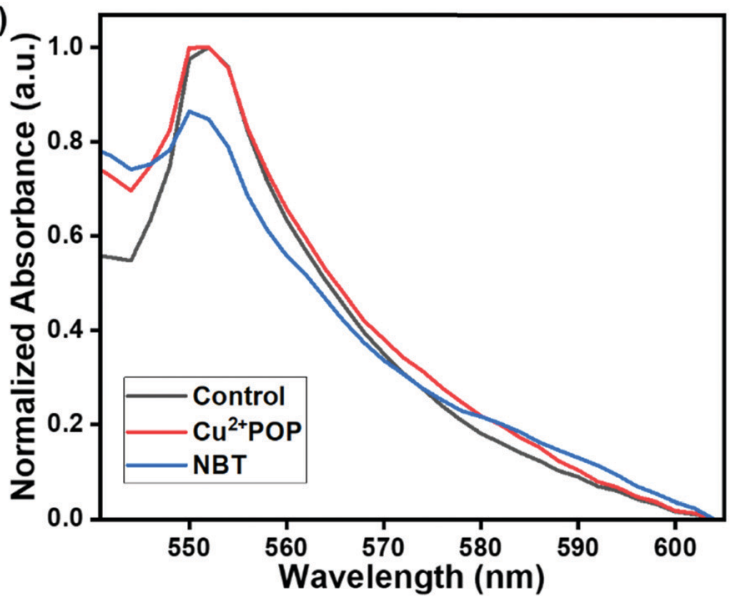

Fig. 8 (a) Scavenging experiment for ROS. (b) NBT for SOD analysis, which has an absorption band at $550 \mathrm{~nm}$ in the presence of riboflavin and light (control). Bare NBT has an absorption band with low intensity. NBT has a strong absorption band at $550 \mathrm{~nm}$ in the presence of $\mathrm{Cu}^{2+}\left(a P O P\right.$ and $\mathrm{H}_{2} \mathrm{O}_{2}$ $\left(\mathrm{Cu}^{2+}\right.$ (aPOP). The absorption band at $550 \mathrm{~nm}$ has increased because of production of superoxide ions $\left(\bullet^{\circ}{ }^{-}\right)$.

inhibition of peroxidase-like activity in the presence of AA and DA were investigated. Fig. 9a schematically illustrates $\mathrm{Cu}^{2+} @ \mathrm{POP}$ catalyzing the conversion of AA to dehydroascorbic acid with inhibition effect. Remarkably, strong blue-colored ox-TMB is (a)
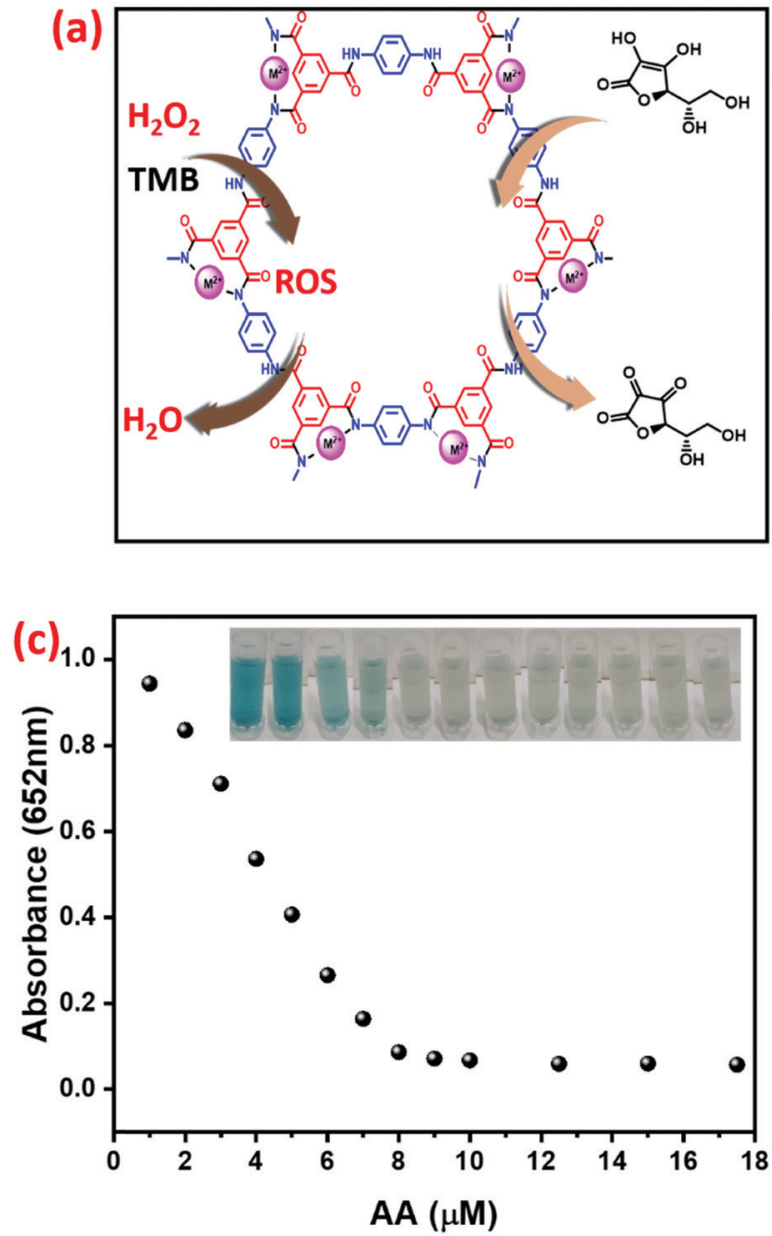
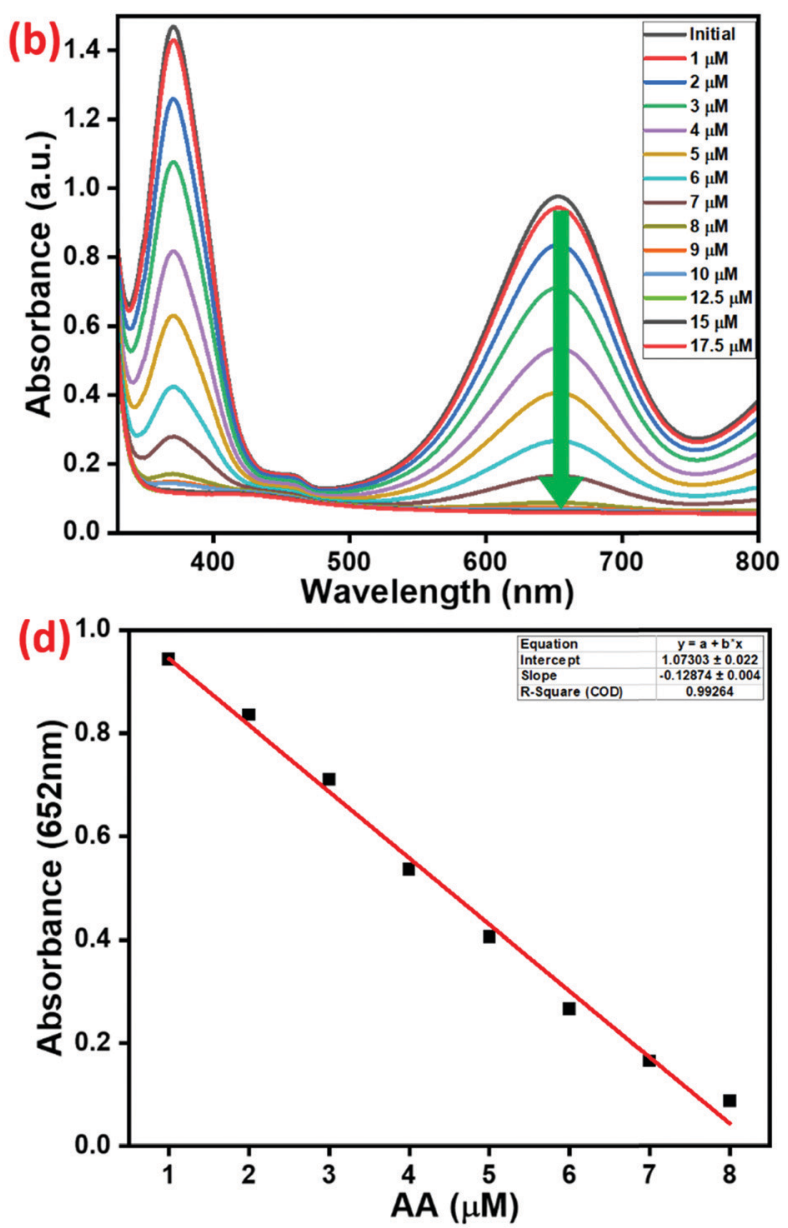

Fig. 9 (a) Schematic illustration of AA to hydroascorbic acid conversion. (b) UV-visible spectra with different concentrations of AA. (c) Relative intensity plot for absorbance versus various concentrations of AA (inset shows optical images of different concentrations of AA in the reaction system). (d) Linear calibration plot for different concentrations of AA. 
evidenced with an absorption band at $652 \mathrm{~nm}$ without AA. Meanwhile, with the addition of AA into the system, immediately the deep color disappeared. Such a color fade indicates the inhibition of oxidation of TMB. Hence, varying the concentration of AA (1-17.5 mM) gradually decreased the absorption spectrum intensity as well as weakening the color. As illustrated in Fig. 9b, the strong absorption band at $652 \mathrm{~nm}$ exhibits a hypochromic shift with increasing concentration of AA. After $8 \mathrm{mM}$ of AA, the absorption peak showed steady-state equilibrium. In Fig. 9c, the relative absorption intensity is plotted versus concentration of AA. The inset digital photographic images show that color disappeared, which confirms the inhibition effect of AA. A linear calibration curve was obtained for absorbance versus concentration of AA with a range of 1-17.5 mM, which exhibited excellent linear correlation, $R^{2}=0.992$, and with low detection limit (Fig. 9d).

\section{DA detection}

Simultaneously, DA also inhibits the peroxidase-like activity of $\mathrm{Cu}^{2+}$ @POP, as extensively investigated. DA converts to aminopurine due to the inhibition of oxidation reaction, as shown in Fig. 10a.

Specifically, in the absence of DA, a significant absorption peak at $652 \mathrm{~nm}$ corresponds to ox-TMB. Moreover, addition of DA into the system inhibits oxidation of TMB. When $2.5 \mu \mathrm{M}$ to $50 \mu \mathrm{M}$ of DA was introduced into the high-peroxidase-active system, apparent color was steadily eliminated to a colorless solution, as shown in Fig. 10b. Up to $20 \mu \mathrm{M}$, DA had an inhibition effect. On further increasing the concentration of DA, the absorption peak obtained a steady state. As shown in Fig. 10c, the relative absorption intensity was plotted versus various concentrations of DA. Inset digital photographic images display color fading, which confirms the inhibition effect and the possibility of naked-eye analysis. The linear calibration curve was plotted of absorbance versus concentration of DA with a range of $2.5-15 \mu \mathrm{M}\left(R^{2}=0.946\right)$ and detection limit was achieved, the result being depicted in Fig. 10d.

\section{Selectivity of AA and DA detection}

In order to analyze the selectivity of prepared $\mathrm{Cu}^{2+} @ P O P$, we conducted a series of experiments with DA, AA, Cy, Fr, G, and cystine (CysC). The results are illustrated in Fig. 11a. According to naked-eye observation, AA and DA showed selective inhibition of peroxidase-like activity with color change as shown in Fig. 11. Further, this was evidently proved from the absorption spectra, and visual color change as displayed in Fig. 11c. The absorption band at $652 \mathrm{~nm}$ is drastically changed in the presence of AA and

\section{(a)}
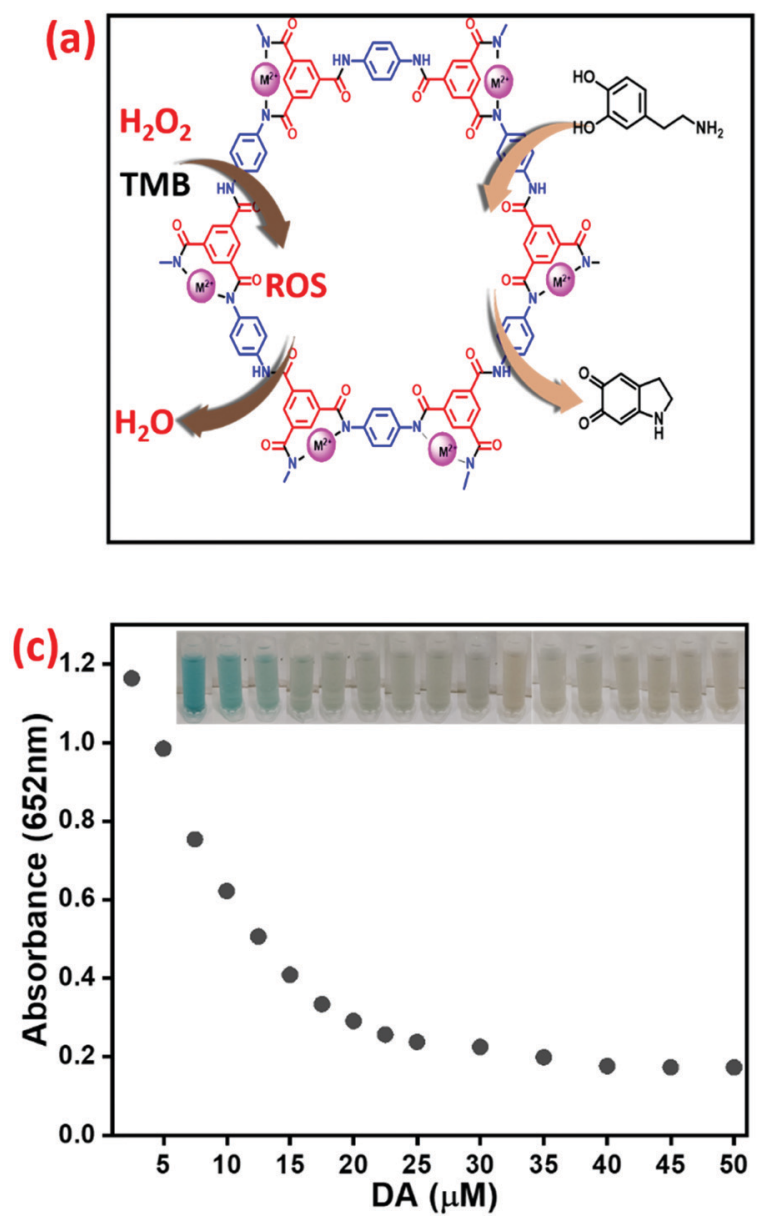
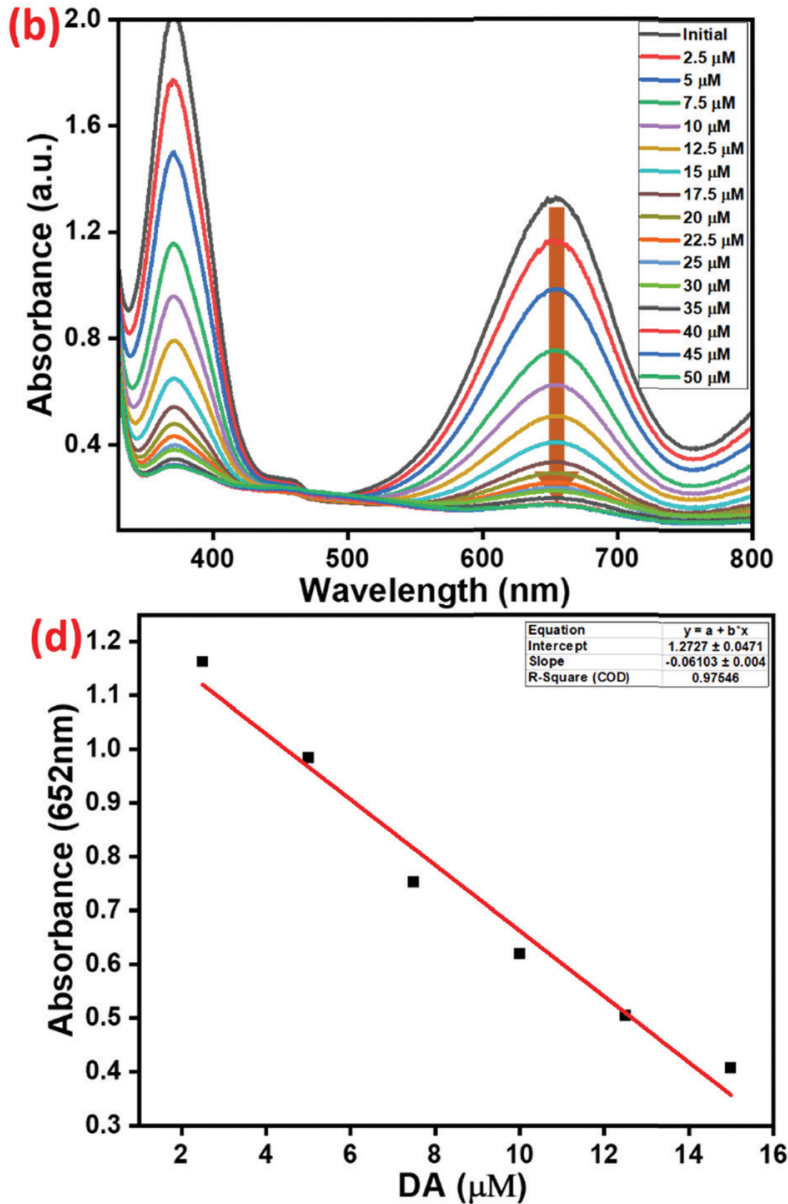

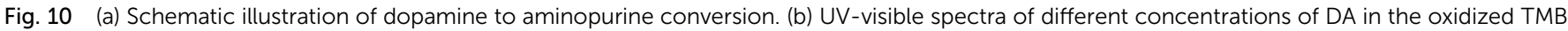

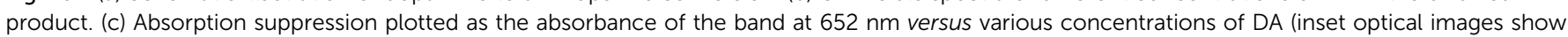
different concentrations of DA in the reaction system). (d) The linear calibration plot for different concentrations of DA in the reaction system. 

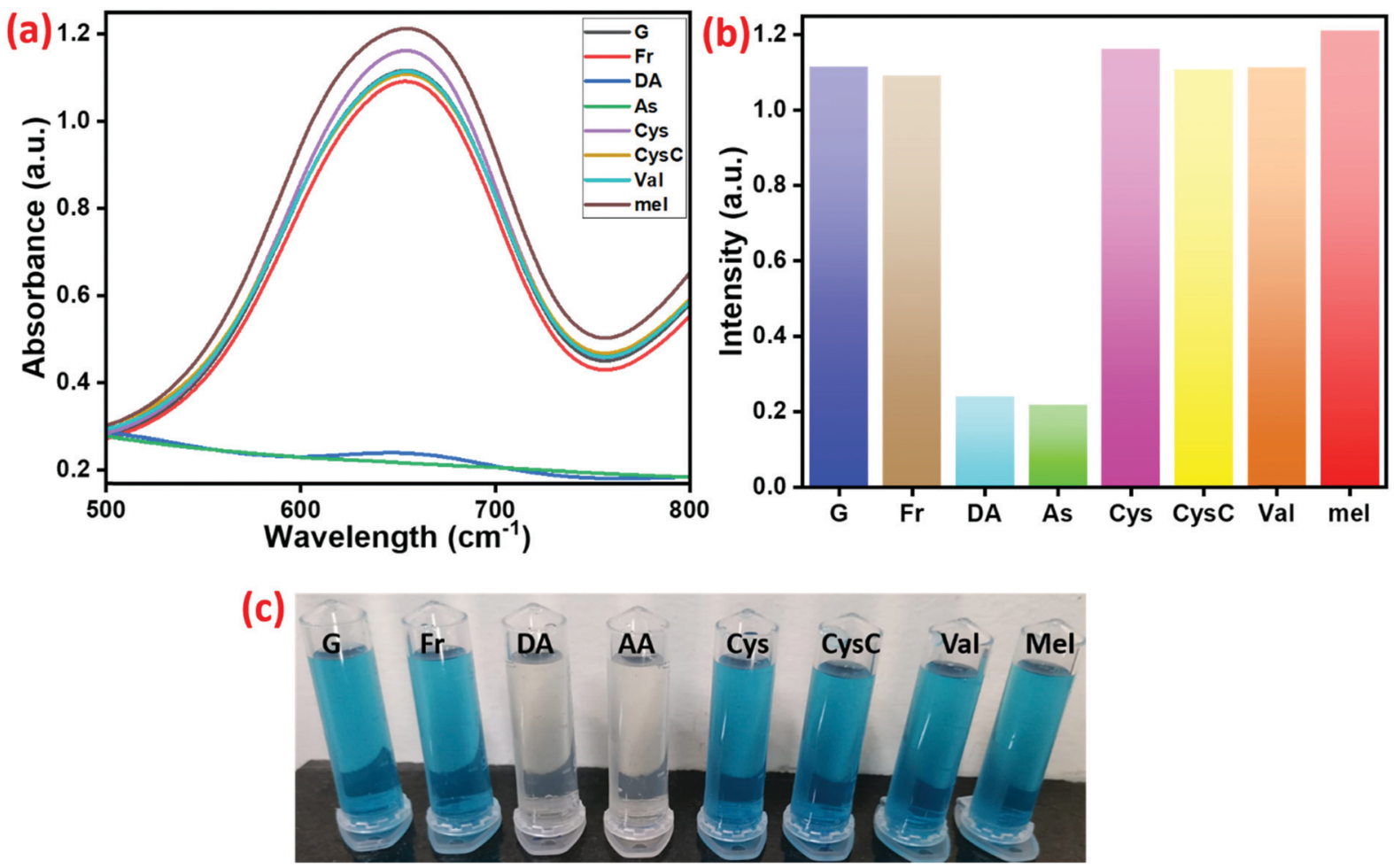

Fig. 11 (a) Selectivity of $\mathrm{Cu}^{2+}$ aPOP towards DA detection in comparison to other interfering substances. (b) Relative detection efficiency bar diagram showing absorbance at $652 \mathrm{~nm}$. (c) Optical images of decolorization in the presence of DA. The standard values are used for selectivity study: TMB (100 $\mu M$ ), $\mathrm{H}_{2} \mathrm{O}_{2}(100 \mu \mathrm{M})$, catalyst solution $\left(0.7 \mathrm{mg} \mathrm{ml}^{-1}\right)$ with $\mathrm{DA}(50 \mu \mathrm{M})$ or other interfering substances $(100 \mu \mathrm{M})$.

Table 1 Comparison table for related copper-based nanozymes

\begin{tabular}{|c|c|c|c|c|c|c|}
\hline No. & Materials & Method & Analytes & Linear range & LOD & Ref. \\
\hline 1 & $\mathrm{Cu}^{2+}$ & $\mathrm{C}$ & DA & $1-50 \mu \mathrm{M}$ & $1 \mathrm{mM}$ & 44 \\
\hline 2 & $\mathrm{CuS} / \mathrm{rGO}$ & $\mathrm{C}$ & DA & $2-100 \mu \mathrm{M}$ & $0.48 \mathrm{mM}$ & 45 \\
\hline 3 & $\mathrm{Cu}-\mathrm{MOXs}$ & $\mathrm{C}$ & DA & $0.5-20 \mu \mathrm{M}$ & $8.6 \mathrm{mM}$ & 46 \\
\hline 5 & $\mathrm{Cu}-\mathrm{HMT}$ & $\mathrm{C}$ & DA & $0.5-3.5 \mathrm{mM}$ & $4.2 \mathrm{mM}$ & 48 \\
\hline 6 & $\mathrm{Cu}^{2+}-\mathrm{g}-\mathrm{C}_{3} \mathrm{~N}_{4}$ & CL & DA & - & - & 16 \\
\hline 7 & $\mathrm{Cu}^{2+}-\mathrm{C}$-dots & CL & DA & - & - & 16 \\
\hline 11 & $\mathrm{Cu}^{2+}-\mathrm{NMOFs}$ & CL & DA & - & - & 21 \\
\hline 12 & $\mathrm{Cu}^{2+}-\mathrm{COF}$ & $\mathrm{C}$ & $\mathrm{MB}$ & $2.5-140 \mu \mathrm{M}$ & - & 22 \\
\hline 13 & $\mathrm{Cu}^{2+}-\mathrm{POP}$ & $\mathrm{C}$ & $\mathrm{DA} \& \mathrm{AA}$ & $2.5-15 \mu \mathrm{M}$ and $1-17.5 \mathrm{mM}$ & $1.4 \mathrm{mM}$ and $1 \mathrm{mM}$ & This work \\
\hline
\end{tabular}

C, colorimetric; CL, chemiluminescence; L, laccase; DA, dopamine; AP, acid phosphatase; Ph, phenols; MB, methylene blue.

DA. Other than AA and DA, there was no obvious inhibition of oxidation of TMB. From this result, we confirmed the high selectivity of $\mathrm{Cu}^{2+}$ @POP to both AA and DA. We compare this with various nanozymes mentioned in the literature ${ }^{49-53}$ and listed in Table 1.

\section{Conclusion}

In summary, the present work has introduced mechanochemically synthesized $\mathrm{M}^{2+}$-coordinated POPs. Interestingly, the asobtained materials exhibited excellent peroxidase-like activity.
Moreover, $\mathrm{Cu}^{2+}$ atoms were uniformly dispersed in $\mathrm{Cu}^{2+} @ \mathrm{POP}$, which is not the case for $\mathrm{Cu}_{0}$ and $\mathrm{Cu}_{\mathrm{x}} \mathrm{O}$. Impressively, $\mathrm{Cu}^{2+} @ P O P$ showed a high peroxidase mimic activity compared to POP, $\mathrm{Ni}^{2+}$ @POP and $\mathrm{Co}^{2+} @$ (POP. The oxidation of TMB catalyzed by $\mathrm{Cu}^{2+} @$ POP can produce blue color corresponding to a single-electron transfer process. Subsequently, the peroxidase-like activity was inhibited in the presence of AA and DA. Based on the inhibition effect, dual detections were realized with low detection limits at $1.3 \mathrm{mM}$ and $1 \mathrm{mM}$ for DA and AA. As-obtained $\mathrm{Cu}^{2+} @ P O P$ has unique characteristics with enhanced peroxidase mimic activity and successfully detected AA and DA via a colorimetric method. 


\section{Conflicts of interest}

There are no conflicts to declare.

\section{Acknowledgements}

The authors acknowledge the "Selective Excellence Research Initiative Fund SRMIST-2021" and Department of Chemistry, SRM Institute of Science and Technology, Tamil Nadu - 603 203, India.

\section{References}

1 H. Wei and E. Wang, Chem. Soc. Rev., 2013, 42, 6060-6093. 2 J. Wu, X. Wang, Q. Wang, Z. Lou, S. Li, Y. Zhu, L. Qin and H. Wei, Chem. Soc. Rev., 2019, 48, 1004-1076.

3 L. Gao, J. Zhuang, L. Nie, J. Zhang, Y. Zhang, N. Gu, T. Wang, J. Feng, D. Yang, S. Perrett and X. Yan, Nat. Nanotechnol., 2007, 2, 577-583.

4 W. W. He, W. G. Wamer, Q. Xia, J. J. Yin and P. P. Fu, J. Environ. Sci. Health, Part C: Environ. Carcinog. Ecotoxicol. Rev., 2014, 32, 186-211.

5 A. AnandBabuChristus, P. Panneerselvamand and A. Ravikumar, Anal. Methods, 2018, 10, 4378-4386.

6 S. Wang, D. Xu and L. Ma, Anal. Bioanal. Chem., 2018, 410, 7145-7152.

7 L. Ai, L. Li, C. Zhang, J. Fu and J. Jiang, Chem. - Eur. J., 2013, 19, 5105-15108.

8 X. Qi, H. Tian, X. Dang, Y. Fan, Y. Zhang and H. Zhao, Anal. Methods, 2019, 11, 1111-1124.

9 M. Muppidathi, P. Perumal, R. Ayyanu and S. Subramanian, Analyst, 2019, 144(9), 3111-3118.

10 T. Zhang, Y. Song, Y. Xing, Y. Gu, X. Yan, H. Liu, N. Lu, H. Xu, Z. Xu, Z. Zhang and M. Yang, Nanoscale, 2019, 11, 20221-20227.

11 L. Zhou, X. Luo, J. Gao, G. Liu, L. Ma, Y. He, Z. Huang and Y. Jiang, Nanoscale Adv., 2020, 2, 1036-1039.

12 T. Zhang, Y. Xing, Y. Song, Y. Gu, X. Yan, N. Lu, H. Liu, Z. Xu, H. Xu, Z. Zhang and M. Yang, Anal. Chem., 2019, 91(16), 10589-10595.

13 M. Marieeswaran and P. Panneerselvam, RSC Adv., 2020, 10, 3705-3714.

14 H. Xu, X. Chen, J. Gao, J. Lin, M. Addicoat, S. Irle and D. Jiang, Chem. Commun., 2014, 50, 1292-1294.

15 E. Y. Choi, P. M. Barron, R. W. Novotny, H. T. Son, C. Hu and W. Choez, Inorg. Chem., 2009, 48(2), 426-428.

16 M. Vázquez-González, W. C. Liao, R. Cazelles, S. Wang, X. Yu, V. Gutkin and I. Willner, ACS Nano, 2017, 11, 3247-3253.

17 S. Wang, R. Cazelles, W. C. Liao, M. Vázquez-González, A. Zoabi, R. Abu-Reziq and I. Willner, Nano Lett., 2017, 17, 2043-2048.

18 Y. Guo, X. Li, Y. Dong and G.-L. Wang, ACS Sustainable Chem. Eng., 2019, 7(8), 7572-7579.

19 W. Li, Y. Li, H. L. Qian, X. Zhao, C. X. Yang and X. P. Yan, Talanta, 2019, 204, 224-228.
20 C. Y. Hu, Z. W. Jiang, C. Z. Huang and Y. F. Li, Microchim. Acta, 2021, 188(8), 1-8.

21 C. H. Chen, M. Vázquez-González, A. Kozell, A. Cecconello and I. Willner, Small, 2018, 14(5), 1703149.

22 Y. H. Xiong, Y. M. Qin, L. J. Su and F. G. Ye, Chem. - Eur. J., 2017, 23, 11037-11045.

23 A. Trewin and A. I. Cooper, Angew. Chem., Int. Ed., 2012, 49(9), 1533-1535.

24 P. Kaur, J. T. Hupp and S. T. Nguyen, ACS Catal., 2011, 1, 819-835.

25 Y. Zhang and S. N. Riduan, Chem. Soc. Rev., 2012, 41, 2083-2094.

26 N. B. McKeown and P. M. Budd, Chem. Soc. Rev., 2006, 35, 675-683.

27 T. Ben, C. Pei, D. Zhang, J. Xu, F. Deng, X. Jinga and S. Qiu, Energy Environ. Sci., 2011, 4, 3991-3999.

28 A. Bhunia, V. Vasylyeva and C. Janiak, Chem. Commun., 2013, 49, 3961-3963.

29 P. M. Budd, B. S. Ghanem, S. Makhseed, N. B. McKeown, K. J. Msayib and C. E. Tattershall, Chem. Commun., 2004, 230-231.

30 H. A. Patel, S. H. Je, J. Park, D. P. Chen, Y. Jung, C. T. Yavuz and A. Coskun, Nat. Commun., 2013, 4, 1357-1363.

31 P. Kaur, J. T. Hupp and S. T. Nguyen, ACS Catal., 2011, 1, 819-835.

32 D. Wu, Y. Li, Y. Zhang, P. Wang, Q. Wei and B. Du, Electrochim. Acta, 2014, 116, 244-249.

33 H. Cheng, X. Wang and H. Wei, Anal. Chem., 2015, 87, 8889-8895.

34 J. S. Aguilar, I. Paris, P. Muñoz, E. Ferrari, L. Zecca and F. A. Zucca, J. Neurochem., 2014, 129, 898-915.

35 P. Belujon and A. A. Grace, Int. J. Neuropsychopharmacol., 2017, 20, 1036-1046.

36 X. Wei, Z. Zhang and Z. Wang, Microchem. J., 2019, 145, $55-58$.

37 H. Tang, P. Lin, H. L. Chan and F. Yan, Biosens. Bioelectron., 2011, 26, 4559-4563.

38 L. Rajput and R. Banerjee, Cryst. Growth Des., 2014, 14(6), 2729-2732.

39 H. Wei, S. Chai, N. Hu, Z. Yang, L. Wei and L. Wang, Chem. Commun., 2015, 51, 12178-12181.

40 L. H. Li, X. Feng, X. Cui, Y. Ma, S. Ding and W. Wang, J. Am. Chem. Soc., 2017, 139, 6042-6045.

41 G. Li, J. Ye, Q. Fang and F. Liu, Chem. Eng. J., 2019, 370, 822-830.

42 Z. Xiaojuan, S. Xifeng, M. A. Abdullah, L. Yonglan and S. Xuping, Inorg. Chem. Front., 2018, 5, 1188-1192.

43 J. W. Rong, G. Z. Hou, Y. Z. Zhi, H. N. Guo and L. Dan, CCS Chem., 2020, 2, 2045-2053.

44 H. B. Wang, Y. Li, G.-L. Dong, T. Gan and Y.-M. Liu, New J. Chem., 2017, 41, 14364-14369.

45 S. Dutta, C. Ray, S. Mallick, S. Sarkar, R. Sahoo, Y. Negishi and T. Pal, J. Phys. Chem. C, 2015, 119, 23790-23800.

46 M. X. Guo and Y. F. Li, Spectrochim. Acta, Part A, 2019, 207, 236-241.

47 F. Liu, J. He, M. Zeng, J. Hao, Q. Guo, Y. Song and L. Wang, J. Nanopart. Res., 2016, 18, 1-9. 
48 M. Marieeswaran and P. Panneerselvam, Mater. Adv., 2021, 2, 7024-7035.

49 B. Liu, Y. Wang, Y. Chen, L. Guo and G. Wei, J. Mater. Chem. $B, 2020,8,10065-10086$.

50 D. Zhu, B. Liu and G. Wei, Biosensors, 2021, 11(8), 53 J. Shah, R. Purohit, R. Singh, A. S. Karakoti and S. Singh, 259.
51 N. S. Vallabani, S. Singh and A. S. Karakoti, Appl. Surf. Sci., 2019, 492, 337-348.

52 N. S. Vallabani, A. S. Karakoti and S. Singh, Colloids Surf., B, 2017, 153, 52-60. J. Colloid Interface Sci., 2015, 456, 100-107. 